Ann. Biol. anim. Bioch. Biophys., 1979, 19 (5), 1631-1640.

\title{
Histochemical demonstration of steroidogenic activity in preimplantation bovine embryos
}

\author{
par A. LAURIA, O. OLIVA, G. AURELI, G. ROGNONI \\ Istifuto di Anatomia degli Animali Domestici con Istologia \\ ed Embriologia dell'Universitò di Milano. \\ Cattedra di Patologia della Riproduzione e Fecondazione \\ Artificiale dell'Università di Milano. \\ Istituto di Zootecnia dell'Università di Milano. \\ Via Celoria 10, 20133 Milano, Italia.
}

Summary. 33-HSD activity has been demonstrated histochemically in bovine Day 6-8 late-morulae and early blastocysts recovered non-surgically from 12 superovulated Friesian heifers. In some embryos grown in vitro from late-morula to enlarged blastocyst in Eagle's enriched medium, this key enzyme in steroidogenesis was clearly demonstrable during all the period of their survival in culture $(96 \mathrm{hrs})$.

These findings are in favour of the capacity of the bovine embryo to synthesize steroids at least in some stages of early development.

In recent years there has been an increasing interest in embryonic endocrinology in the initial stages of development, i.e. bofore implantation on the uterine wall. One of the most important factors justifying such an interest is the need to know when and by which processes the fertilized ovum signals its presence to the maternal organism in order to establish the pregnancy. The rapid diffusion of embryo transfer methodology both in laboratory and in farm animals has further stimulated investigations on this and on other important metabolic functions of the early embryo.

At present, numerous findings prove the presence in the preimplantation blastocyst of steroid hormones and of enzymes involved in their metabolism and interconversion. However, the data reported by various workers on this subject are not univocal, and are often difficult to correlate because they are the result of investigations from different standpoints and in different species.

The embryo's capacity to synthesize steroid hormones at a very early stage was revealed as early as 1966, when Huff and Eik-Nes demonstrated that the Day 6 rabbit blastocyst could biosynthesize in vitro cholesterol and pregnenolone from acetate. Further biochemical investigations have evidenced the presence of progesterone, cstrogens and other steroids in the blastocyst and/or in the blastocele fluid of the rabbit (Seamark and Lutwak-Mann, 1972 ; Eik-Nes et al., cit. by Lutwak-Mann, 1971 ; 
Fuchs and Beling, 1974 ; Borland ef al., 1977 ; Fujimoto and Sundaram, 1978 ; Singh and Booth, 1978) and of the pig (Perry et al., 1973 ; 1976 ; Heap et al., 1975).

On the other hand the uterine fluid contains large amounts of progesterone (Seamark and Lutwak-Mann, 1972 ; Fuchs and Beling, 1974 ; Cowman et al., 1976 ; Borland et al., 1977 ; Fowler et al., 1977) and œstrogens (Dickmann ef al., 1975 ; Borland ef al., 1977). This has induced many workers to assume that the hormones found in the preimplantation blastocyst have an uterine origin (Seamark and LutwakMann, 1972 ; Borland ef al., 1977 ; Fujimoto and Sundaram, 1978 ; Singh and Booth, 1978). This hypothesis seems to be confirmed also by the scarcity of smooth endoplasmic reticulum and tubular mitochondria (Borland ef al., 1977) and by the marked pinocylotic activity (Beier and Maurer, 1975) shown in rabbit blastocyst. This opinion is not shared by other authors who suppose that the embryo signals its presence by some active processes, and in some species, at least, this appears to involve the synthesis of hormonal substances (Perry ef al., 1976).

Biochemical investigations have evidenced that the unconjugated œstrogens and progesterone found in the pig blastocyst are synthesized in situ and not maternally derived (Perry et al., 1973), and that the blastocyst is capable of converting in vitro dehydroepiandrosterone and androstenedione to œstrogens (Heap ef al., 1975). In this species the synthesis of steroid hormones is supposed to start, as also histochemically proved by Flood (1974), on Day 12 prior to the implantation of the blastocyst. These findings can be related to recent data which are in favour of the very early synthesis of a gonadotropin-like substance by the embryos of rabbits (Haour and Saxena, 1974 ; Fuchs and Beling, 1974), mice (Wiley, 1974), humans (Saxena ef al., 1974) and pigs (Perry et al., 1976). According to Perry et al. (1976) this fact supports the hypothesis of an autostimulation of embryonic steroidogenesis.

In favour of steroid synthesis by the preimplantation embryo are numerous histochemical findings which have demonstrated the presence of key enzymes involved in both the metabolism and the interconversion of such hormones. $\Delta 5-3 \beta$ - and $17 \beta$ hydroxysteroid dehydrogenase (HSD) have been evidenced in the morulae and blastocysts of the rat (Dickmann and Dey, 1973, 1974a, b ; Dey and Dickmann, 1974a ; Dickmann, 1975), mouse (Dey and Dickmann, 1974b), rabbit (Dickmann et al., 1975) and hamster (Dickmann and Gupta, 1974 ; Niimura and Ishida, 1976). According to Dickmann (1975) the autonomous production by the preimplantation embryo of steroid hormones plays an imporiant role in the regulation of embryonic metabolism, in the transformation of the morula to blastocyst, in the loss of the zona pellucida and in implantation.

The data on this subject in the literature on bovines are scarce, relating mostly to the endocrine processes regulating implantation. In particular the role of cstrogens in this stage has been studied biochemically (Eley ef al., 1975 ; Robertson and King, 1975). Robertson et al. (1976) have demonstrated the production of cestronesulphate by the Day 30 bovine embryo. According to these authors, who have demonstrated also in the sheep and the pig cstrone-sulphate embryonic synthesis before the establishment of vascular connection with the mother, this substance could diffuse through the embryo membranes and reach the uterine wall where it might be reduced by a sulphatase into biologically active $17 \beta$-œstradiol.

On the other hand it is generally agreed that insufficient knowledge of the meta- 
bolic processes of the early bovine embryo is a factor which considerably limits success in transfer pratices, especially when the embryos are culfured in vitro longer than a limited number of hours (Seidel, 1977).

No information is available so far in the literature on the endocrine activities of the bovine embryo in its earlier stages of development.

The purpose of this paper is therefore to contribute to the knowledge of this important aspect of the metabolic behaviour of the bovine late-morula and early blast - cyst collected between Days 5 and 8 after fertilisation, i.e. when, in embryo transfer practices, the fertilised ova are flushed from the donor and transferred into the recipient.

\section{Materials and methods.}

For this investigation, which is part of a research program on embryo transfer, we used 52 morphologically normal latemorulae and early blastocysts recovered from 12 superovulated Friesian heifers and flushed non-surgically Days 6-8 after artificial insemination using the method applied by the Institute of Animal Physiology of the A. R. C. at Cambridge (Newcomb ef al., 1978a, b). All the embryos were classified according to their morphology and stage of development. A part of them was used immediately after recovery; the remaining part was cultivated in small test tubes stoppered with silicon rubber. During the subsequent 5 days some embryos were recovered from the tubes every $24 \mathrm{hrs}$ after evaluation of the morphological features and the stage of development.

For the study of steroidogenic activity, histoenzymological reactions for $3 \beta-$ HSD were performed according to Wattenberg (1958), Baillie and Griffiths (1964), Baillie et al. (1966a, b) and Jones et al. (1968). The embryos were incubated for $20 \mathrm{~min}$; the substrates used were dehydroepiandrosterone (DHE) and $\Delta 4$-androsten- $3 \beta$ $17 \beta$-diol. The same substrate-free solutions were used for control. Starting from Day 4 , reactions for lactic and succinic dehydrogenase activity were performed according to Pearse $(1961 a, b)$.

The following culture medium was used : $0.12 \mathrm{~g} \mathrm{L-glutamine;} 0.045 \mathrm{~g}$ yeast extract ; $45 \mathrm{ml} 5$ p. 100 lactalbumin hydrolisate ; $0.878 \mathrm{~g}$ triptose phosphate broth ; $0.0378 \mathrm{mg} \mathrm{Fe}\left(\mathrm{NO}_{3}\right) .9 \mathrm{H}_{2} \mathrm{O} ; 100,000 \mathrm{lU} \mathrm{G}$ sodium penicillin ; $0.1 \mathrm{~g}$ streptomicin sulphate; $0.1 \mathrm{~g}$ neomicin sulphate ; $12.5 \mathrm{ml} 0.1 \mathrm{p} .100$ phenol red ; $200 \mathrm{ml}$ bovine fotal serum and Eagle's minimum essential medium to $1,000 \mathrm{ml}$. Sodium bicarbonate was added to reach $\mathrm{pH} 7.27 .3$.

\section{Results.}

All the embryos used showed good morphological features and were accompanied by a zona pellucida except for a number of the more advanced blastocysts recovered on Day 8 . The embryos were at different stages of development, ranging from the morula with many blastomers to the blastocyst with an evident blastocele.

Histoenzymological reactions for $3 \beta-H S D$ performed $1 \mathrm{hr}$ after recovery were always markedly positive in both morulae and blastocysts. Numerous formazan precipitates were present in the cytoplasm of blastomers. However, since the reactions 
have been carried out on the embryos in toto, it has not always been possible to identify with precision the zones where the reaction was more or less intense. In the embryos in an intermediate stage between morula and blastocyst it was even possible to identify cells with such marked positivity that the negative nucleus was evident among formazan precipitates (fig. 1). The zona pellucida was always negative. Among the different techniques used, the best reults were achieved with the method of Jones ef al. (1968) using $\Delta 4$-androsten-3 $\beta-17 \beta$-diol as a substrate, whereas reactions with DHE were always weaker and more diffused. The results obtained with other techniques (Wattenberg, 1958 ; Baillie and Griffiths, 1964 ; Baillie ef al., 1966a, b) were substantially similar but the positivity was less marked and localized. No formazan precipitates were present in embryos incubated with substrate-free solutions (fig. 2).

After 24 hrs in culture the embryos further developed and the most evident progress was noted in embryos recovered at the stage of morula. In many of them the beginning of the formation of the blastocyst cavity was detectable. The reactions for $3 \beta-H S D$ showed a pattern of positivity similar to that described above in the embryos just recovered.

After 48 hrs in culture the blastocysts appeared larger in volume, in more advanced stages of development, and often well preserved. The rupture of the zona pellucida always occurred. 33-HSD activity was still present in all the embryos examined.

After $72 \mathrm{hrs}$ in culture, other embryos besides those with evident morphological alterations showed morphological symptoms of incipient suffering; in some considerably enlarged and completely hatched blastocysts $3 \beta-H S D$ activity was still present and well localized even though weakened in general (figs. 3, 4).

After $96 \mathrm{hrs}$ in culture, all the remaining embryos showed symptoms of acute suffering; a weak positivity to the $3 \beta-\mathrm{HSD}$ reaction could be observed in only two blastocysts which appeared less damaged than the others.

Given the limited number of embryos available, the reactions for respiratory enzymes were performed only in the more advanced cultures. It was thus possible to demonstrate that after $72 \mathrm{hrs}$ in culture, lactic and succinic dehydrogenases were clearly present. These activities, though weak, were also present after $96 \mathrm{hrs}$ of culture.

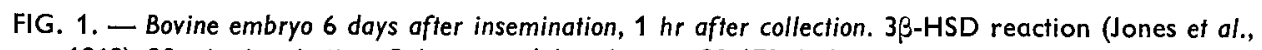
1968). $20 \mathrm{~min}$. incubation. Substrate : $\Delta 4$-androsten-3 $\beta$ - $17 \beta$-diol.

FIG. 2. - As fig. 1, control.

FIG. 3. - Bovine embryo collected at the same stage as the one shown in fig. 1 developed in culture for

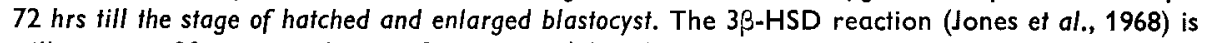
still positive, $20 \mathrm{~min}$. incubation. Substrate : $\Delta 4$-androsten-3 $\beta$-17 $\beta$-diol.

FIG. 4. - Same as fig. 3. Larger magnification showing the cyfoplasmic localization of formazan granules and the negativity of nuclei. 

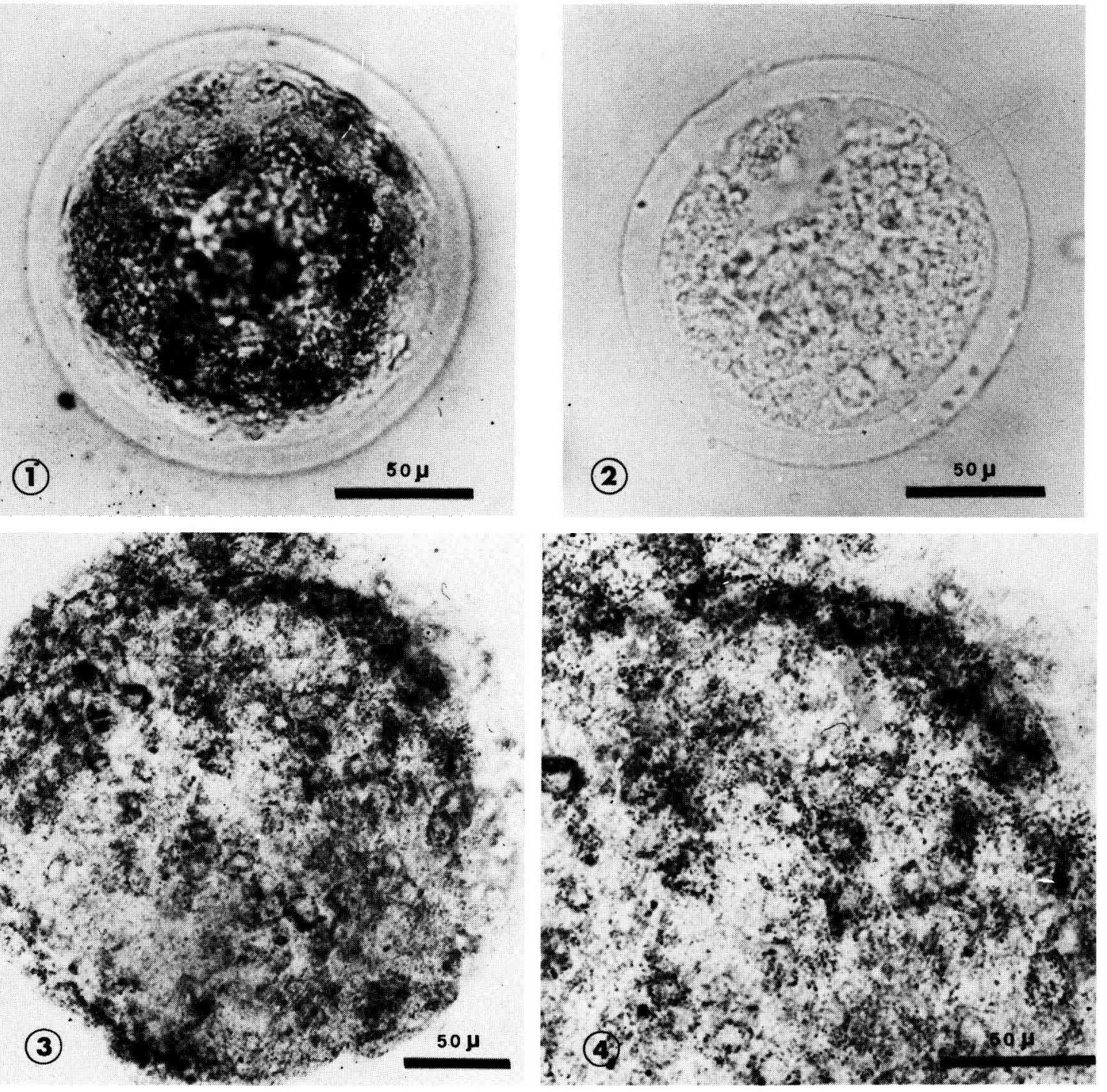


\section{Conclusions.}

Our results have shown the presence of $3 \beta-H S D$, a key enzyme for steroid hormone synthesis, in bovine latemorulae and early blastocysts recovered on Days 6-8 after fertilization. This activity is present in the embryo even in culture for the whole period during which it can develop in vitro. The intensity and the localization of such activity gradually diminuish with the increase of morphological symptoms of suffering.

These results are in accordance with those obtained by other authors on laboratory animals. Dickmann ef al. (1975) demonstrated histochemically the presence of $\triangle 5-3 \beta-H S D$ activity in rabbit embryos from the 78th hour post-coltum ( $p$. c.) till the 168 th hour, i.e. shortly after implantation. It is significant that these authors found $163 \beta$-HSD-negative rabbit morulae out of 40 at 72 hrs p.c., thus suggesting a drop or even a cessation of steroidogenesis at that time. Dey and Dickmann (1974) and Dickmann and Dey $(1973,1974 a)$ also demonstrated $\Delta 5-3 \beta-H S D$ activity in rat embryos starting from Day 4 p.c. Such activity decreased from Day 6 and was no longer detectable on Day 7. In hamster embryos, according to Dickmann and Gupta (1974), $\Delta 5-3 \beta-H S D$ activity appears at three days p.c. and cannot be demonstrated on Days 5-6, whereas more recently Niimura and Ishida (1976) also evidenced the presence of this enzyme in unfertilized eggs and, after fertilization, from the 1-and 2-cell stage till the blastocyst stage ; this discrepancy with the data of Dickmann and Gupta (1974) is probably due to a difference in the incubation time and in the substrates used.

On the other hand, the endocrine activities of embryos from other species have been demonstrated in more advanced stages of development, i.e. shortly before or after implantation. $\Delta 5-3 \beta-H S D$ activity in pig embryos was studied histochemically by Flood (1974), starting from Day 10 after fertilization. This enzyme, not detectable on Day 10, is present from Day 12, the period when the first connections are established between the embryos and the uterus in the pig. These data, together with those obtained by the same worker on other enzyme activities involved in steroidogenesis, coincide with the biochemical findings of Perry ef al. (1973) which prove that the pig blastocyst at that time produces unconjugated œstrogens and progesterone, and that œstrone and cestradiol are synthesized in vitro from neutral steroids.

On the other hand many workers have demonstrated histochemically the presence of $3 \beta-H S D$ during and immediately after implantation in the trophoblast of the rat (Deane ef al., 1962) ; Deane and Rubin, 1965 ; Ferguson and Christie, 1967 ; Schmidt et al., 1970 ; Legrand and Hung, 1972 ; Legrand, 1975 ; Marcal et al., 1975), mouse (Botte et al., 1968 ; Chew and Sherman, 1973, 1975), guinea pig (Ferguson and Christie, 1967) and hamster (Legrand, 1977). Legrand (1977), also doing experimental studies, asserts that the HSD activities of the hamster trophoblast are autonomous, not depending on maternal hormone control. This also seems to be the case of the mouse in which Chew and Sherman (1975) have biochemically demonstrated that in the trophoblast $\Delta 5-3 \beta-H S D$ activity can be monitored both in vitro and in vivo.

Chew and Sherman (1975) have also proved that trophoblastic cells in culture are capable of forming progesterone and of secreting it in the medium. Eley et al. 
(1975), Robertson and King (1975) and Robertson ef al. (1976) have demonstrated that bovine, pig and sheep embryos synthesize steroid hormones even before the vascular connections with the mother are established.

It should also be stressed that the presence of steroid hormones in the blastocyst is substantiated by numerous biochemical data on the rabbit (Seamark and LutwakMann, 1972 ; Fuchs and Beling, 1974 ; Dickmann ef al., 1975 ; Borland ef al., 1977 ; Fujimoto and Sundaram, 1978 ; Singh and Booth, 1978) and pig (Perry ef al.,1973, 1976 ; Heap ef al., 1975), even though some authors (Seamark and Lutwak-Mann, 1972 ; Borland ef al., 1977 ; Fujimoto and Sundaram, 1978) maintain that these hormones are not produced by the embryo but are of maternal origin.

Regardless of the various opinions on the endocrine autonomy of the embryo and its meaning, it is a fact that our data demonstrate that the bovine embryo in advanced morula and early blastocyst stages possesses a key enzyme for steroidogenesis and retains it for a number of days in culture. It must also be taken into consideration that recent data are in favour of an early blastocyst synthesis of LH- or HCG-like substances in rabbit (Haour and Saxena, 1974 ; Fuchs and Beling, 1974), rat (Wiley, 1974), humans (Saxena ef al., 1974) and pig (Perry ef al., 1976). The function of these substances is supposed to be the autostimulation of embryonic steroidogenesis (Perry ef al., 1976).

On the basis of the above, the logical extension of our work will include, concomitantly with ultrastructural research :

1) The study of the behaviour of the enzymes involved in steroid hormone synthesis, covering all the stages of embryonic development from fertilization to implantation in order to (i) determine the appearance and the duration of such activities and (ii) to clarify the significance of their presence among the complex, and yet little-known, endocrinological phenomena regulating the first stages of pregnancy;

2) Culture of the embryo in vitro under more favourable conditions and with culture media permitting the embryo to reach more advanced stages of development. Particular attention will also be given to the substances secreted in the culture medium; these investigations will not be confined to the substances involved in steroidogenic mechanisms, but would also cover all the substances which could play an important role in embryo implantation, including prostaglandins (Evans and Kennedy, 1977).

Notwithstanding the obvious difficulties, especially with bovines, this research program is both urgent and esential. It is our belief that the results will supply information useful in achieving better results in embryo transfer practices, particularly when the interval from recovery to transfer into the recipient is longer than a restricted number of hours.

EEC Seminar on « Ovarian stimulation and egg quality in mammals ", Luynes, France, octobre 1978. 
Acknowledgments. - Supported by C. N. R.-F. P. «Biology of Reproduction».

Résumé. Chez les bovins, l'activité $3 \beta-H S D$ a été démontrée histochimiquement aux jours 6-8 dans des morulas tardives et des blastocystes précoces prélevés non chirurgicalement chez 12 génisses Frisonnes superovulées. Dans quelques embryons cultivés in vitro à partir de la morula fardive jusqu'au blastocyste développé dans un milieu Eagle enrichi, cet enzyme vital de la stéroïdogenèse a été clairement montré pendant toufe la période de leur survie en culture $(96 \mathrm{~h})$. Ces résultats sont en faveur de la capacité de l'embryon bovin à synthétiser des stéroïdes au moins à quelques étapes de son développement précoce.

\section{References}

BAILLIE A. H., CALMAN K. C., FERGUSON M. M., HART D. McK., 1966a. Histochemical utilization of $3 \alpha-, 6 \beta-, 11 \alpha-, 12 \alpha-, 16 \alpha-, 16 \beta-, 17 \alpha-, 21$ and 24 Hydroxysteroids. J. Endocrinol., 34, 1-12.

BAILLIE A. H., FERGUSON M. M., HART D. McK., 1966b. Developments in steroid histochemistry. Acad. Press, London.

BAILLIE A. H., GRIFFITHS K., 1964. 33-hydroxysteroid dehydrogenase in the mouse Leydig cell. J. Endrocrinol., 29, 9-17.

BEIER H. M., MAURER R. R., 1975. Uteroglobin and other proteins in rabbit blastocyst fluid after development in vivo and in vitro. Cell Tiss. Res., 159, 1-10.

BORLAND R. M., ERIKSON G. F., DUCIBELLA T., 1977. Accumulation of steroids in rabbit preimplantation blastocyst. J. Reprod. Fert., 49, 219-224.

BOTTE V., TRAMONTANA S., CHIEFFI G., 1968. Histochemical distribution of some hydroxysteroid dehydrogenases in the placenta, fotal membranes and uterine mucosa of the mouse. J. Endocrinol., 40, 189-194.

CHEW N. J., SHERMAN M. I., 1973. $\triangle 5-3 \beta-H S D$ activity in mouse giant trophoblast cells in vivo and in vitro. Biol. Reprod., 9, 79-80.

CHEW N. J., SHERMAN M. I., 1975. Biochemistry of differentiation of mouse trophoblast : $\Delta 5$, $3 \beta$ HSD. Biol. Reprod., 12, 351-359.

COWMAN B. D., MANES C., HAGERMAN D. D., 1976. Progesteron concentration in rabbit uterine flushings before implantation. J. Reprod. Fert., 47, 359-361.

DEANE H. W., RUBIN B. L., 1965 . Identification and control of cells that synthesize steroid hormones in the adrenal glands, gonads and placentae of various mammalian species. Arch. Anat. microsc. Morph. exp., 54, 49-65.

DEANE H. W., RUBIN B. L., DRICKS E. C., LOBEL B. L., LEIPSNER G., 1962. Trophoblastic giant cells in placenta of rats and mice and their probable role in steroid hormon production. Endocrinology, 70, 407-419.

DEY S. K., DICKMANN Z., 1974a. $\triangle 5$-3ß-HSD activity in rat embryos on day 1 through 7 of pregnancy. Endocrinology, 95, 321-322.

DEY S. K., DICKMANN Z., 1974b. $\triangle 5-3 \beta-H S D$ activity in mouse morulae and blastocysts. 7 th. annu. Meet. Soc. Study Reprod., Abstr., 150.

DICKMANN Z., 1975. Steroidogenesis in preimplantation embryos. Res. Reprod., 1, 3.

DICKMANN Z., DEY S. K., 1973. Two theories : the preimplantation embryo is a source of steroid hormones controlling morula-blastocyst transformation, and implantation. J. Reprod. Fertil., 35, 615-616.

DICKMANN Z., DEY S. K., 1974a. Steroidogenesis in the preimplantation rat embryo and its possible influence on morula-blastocyst transformation and implantation. J. Reprod. Fert., 37, 91-93.

DICKMANN Z., DEY S. K., 1974b. Evidence that $\triangle 5-3 \beta-H S D$ activity in rat blastocyst is autonomous. J. Endocrinol., 61, 513-514.

DICKMANN Z., GUPTA J. S., 1974. $\triangle 5$-3 $\beta$-HSD and Estradiol-173-HSD activify in preimplantation hamster embryos. Develop. Biol., 40, 196-198. 
DICKMANN Z., DEY S. K., GUPTA J. S., 1975. Steroidogenesis in rabbit preimplantation embryos. Proc. nat. Acad. Sci. U. S. A., 72, 298-300.

ELEY R. M., THATCHER W. W., BAZER F. W., 1975. Hormone changes associated with bovine conceptus development. J. Anim. Sci., 41, 350-351.

EVANS C. A., KENNEDY T. G., 1977. Proc. can. Fed. Biol. sci., 20, 168. Cited by EVANS C. A., KENNEDY T. G., 1978. Evidence against a role for blastocyst steroidogenesis in the initiation of implantation in the hamster. Biol. Reprod., 18, Suppl. 1, 134-135.

FERGUSON M. M., CHRISTIE G. A., 1967. Distribution of hydroxysteroid dehydrogenases in the placentae and fœital membranes of various mammals. J. Endocrinol., 38, 291-306.

FLOOD P. F., 1974. Steroid metabolizing enzymes in the early pig conceptus and in the related endometrium. J. Endocrinol., 63, 413-414.

FOWLER R. E., JOHNSON M. H., WALTERS D. E., EAGER D. D., 1977. The progesterone content of rabbit uterine flushing. J. Reprod. Fert., 50, 301-308.

FUCHS A. R., BELING C., 1974. Evidence for early ovarian recognition of blastocysts in rabbits. Endocrinology, 95, 1054-1058.

FUIIMOTO S., SUNDARAM K., 1978. The source of progesterone in rabbit blastocysts. J. Reprod. Fert., 52, 231-233.

HAOUR F., SAXENA B. B., 1974. Detection of a gonadotropin in rabbit blastocyst before implantation. Science, N. Y., 185, 444-445.

HEAP R. B., PERRY J. S., GADSBY J. E., BURTON R. D., 1975. Endocrine activities of the blastocyst and early embryonic tissue in the pig. Trans. Biochem. Soc., 3, 1183-1188.

HUFF R. L., EIK-NES K. B., 1966. Metabolism in vitro of acetate and certain steroids by six days old rabbit blastocysts. J. Reprod. Fert., 11, 57-63.

JONES G. E. S., GOLDBERG B., WOODRUFF J. D., 1968. Cell specific steroid inhibitions in histochemical steroid 33-ol-HSD activities in man. Histochemie, 14, 131-142.

LEGRAND C., 1975. La fonction stéroidogène du trophoblaste intra-artériel chez la ratte. Eur. J. Gynec. Obstet., Biol. Reprod., 4, 1017-1035.

LEGRAND C., 1977 . Histochemical distribution of $\Delta 5-3 \beta$ and $17 \beta-H S D$ in hamster trophoblast. J. Reprod. Fertil., 51, 405-408.

LEGRAND C., NGUYEN SON HUNG, 1972. Mise en évidence d'une activité stéroidodéshydrogénasique dans le trophoblaste intra-artériel chez la ratte gestante. C. $R$. Acad. Sci. Paris, Sér. D, 275, 1513-1515.

LUTWAK-MANN C., 1971. The rabbit blastocyst and its environment : physiological and biochemical aspects, 243-260. In BLANDAU R. J., The biology of the blastocyst. Univ. Chicago Press, Chicago.

MARCAL J. M., CHEW N. J., SALOMON D. S., SHERMAN M. I., 1975. $\triangle 5-3 \beta-H S D$ activities in rat trophoblast and ovary during pregnancy. Endocrinology, 96, 1270-1279.

NEWCOMB R., CHRISTIE W. B., ROWSON L. E. A., 1978a. Non-surgical recovery of bovine embryos. Vet. Rec., 102, 414-417.

NEWCOMB R., CHRISTIE W. B., ROWSON L. E. A., 1978b. Comparison of the fetal survival rate in heifer after the transfer of an embryo surgically to one uterine horn and non-surgically to the other. J. Reprod. Fertil., 52, 395-397.

NIIMURA S., ISHIDA K., 1976. Histochemical studies of $\Delta 5-3 \beta-H S D, 20 \alpha-$ and $20 \beta-H S D$ and possible progestagen production in hamster eggs. J. Reprod. Fertil,, 48, 275-278.

PEARSE A. G. E., 1961a. Method for succinate dehydrogenase using nitro-BT/MTT, 910. In Histochemistry theoretical and applied. Churchill J. A. Ltd., London.

PEARSE A. G. E., 1961b. Methods for demonstration of DPN- and TPN-linked dehydrogenases, 911. In Histochemistry theoretical and applied. Churchill J. A. Lid., London.

PERRY J. S., HEAP R. B., AMOROSO E. C., 1973. Steroid hormone production by pig blastocyst. Nature, London, 245, 45-47.

PERRY J. S., HEAP R. B., GADSBY J. E., BURTON R. D., 1976. Endocrinology of the blastocyst and its role in the establishment of pregnancy. J. Reprod. Fert. Suppl. 25, 85-104.

ROBERTSON H. A., KING G. J., 1975. Estrogens and placental attachment in the cow. J. Anim. Sci., 41, 377.

ROBERTSON H. A., KING G. J., CARNEGIE J. A., 1976. Diestrone sulphate and embryonic attachment in the cow, ewe and sow. Proc. 8th. int. Congr. Anim. Reprod. A. I., Krakow, 3, 313-315. 
SAXENA B. B., HASAN S. H., HAOUR F., SCHMIDT-GOLLWITZER M., 1974. Radioreceptor assay of human chorionic gonadotropin : detection of early pregnancy. Science N. Y., 184, 793-795.

SCHMIDT W., WENDLER D., GABLER W., 1970. Aktivität und Lokalization verscheidener steroide hydrogenasen (St DH) während der Plazentation der Ratte. Acta Histochem., 38, 318-325.

SEAMARK R. F., LUTWAK-MANN C., 1972. Progestins in rabbit blastocysts. Reprod. Fertil., 29, $147-148$.

SEIDEL G. E., 1977. Short term maintenance and culture of embryos, 20-24. In BETTERIDGE K. J., Embryo transfer in farm animals. Dpt. Agric. Ottawa, Canada.

SINGH M. M., BOOTH W. D., 1978. Studies on the metabolism of neutral steroids by preimplantation rabbit blastocysts in vitro and the origin of blastocyst cestrogen. J. Reprod. Fert., 53, 297304.

WATTENBERG L. W., 1958. Microscopic histochemical demonstration of steroid-3ß-ol dehydrogenase in tissue sections. J. Histoch. Cytoch., 6, 225-232.

WILEY L. D., 1974. Presence of a gonadotropin on the surface of preimplanted mouse embryos. Nalure, London, 252, 715-716. 